\title{
Miedź, nikiel, ołów i cynk w strefach wpływu eksploatacji złóż miedzi Dolnego Śląska
}

\author{
Agata Duczmal-Czernikiewicz ${ }^{1}$, Natalia Hoska ${ }^{2}$, Marcin Zimny ${ }^{3}$, Daniel Zimny ${ }^{1}$
}

\begin{abstract}
Copper, nickel, lead and zinc in the zones affected by exploitation of copper deposits in the Lower Silesia. Prz. Geol., 67: 154-155; doi: $10.7306 / 2019.5$

A b s t r a c t. Base metals ( $\mathrm{Cu}, \mathrm{Zn}$ and $\mathrm{Pb}$ ) as the main resources of the Lower Silesian copper deposits have significantly been influenced by different enviromental factors. In this paper, changes in metal concentrations on the surface in relation to deeper layers of the sediments were examined. The concentration of metals in the whole sediment, and in selected grain fractions was studied. The contents of these metals in the soils of areas adjacent to the deposit are diverse and are in the range of: $3.0-1082.9 \mathrm{mg} / \mathrm{kg} \mathrm{Cu}$; $3.5-106.1 \mathrm{mg} / \mathrm{kg} \mathrm{Pb} ; 27.6-49.3 \mathrm{mg} / \mathrm{kg} \mathrm{Zn}$, and $1.33-23.0 \mathrm{mg} / \mathrm{kg} \mathrm{Ni}$ in the old deposit district and $\mathrm{Cu} 0.91-1655.0 \mathrm{mg} / \mathrm{kg} \mathrm{Pb}$; $10.0-1792.0 \mathrm{mg} / \mathrm{kg} \mathrm{Zn} ; 3.38-1129.0$ and $0.47-32.7 \mathrm{mg} / \mathrm{kg} \mathrm{Ni}$ in the new deposit district. The increase of metal concentration in the fine fractions has been observed. Moreover, the decrease in the metal content with depth was observed in all investigated profiles.
\end{abstract}

Keywords: copper, nickel, zinc, lead, soils, sediments, Lower Silesia

Na obszarze starego zagłębia miedziowego (w rejonie Iwin i Złotoryi na Pogórzu Kaczawskim) rudy miedzi eksploatowano od XIX w. w złożach Konrad, Lena i Nowy Kościół. W 1957 r. odkryto złoża na monoklinie przedsudeckiej w okolicy Lubina i Głogowa (nowe zagłębie miedziowe), gdzie w 1968 r. wybudowano zakłady przeróbcze (Konstantynowicz, 1971), które nadal prowadzą eksploatację. Rudę miedzi stanowią minerały z grupy siarczków i siarkosoli, występujące w piaskowcach czerwonego spągowca oraz łupkach, wapieniach i dolomitach cechsztynu. Ze względu na zawartość metali najważniejszą częścią złoża jest łupek miedzionośny położony na granicy pomiędzy utworami lądowymi i morskimi cechsztynu (Oszczepalski, 1999). Wcześniejsze badania geochemiczne dotyczące rozproszenia metali $\mathrm{w}$ osadach, prowadzono $\mathrm{w}$ rejonach hut miedzi i otoczenia osadników (Kijewski, 1995). Na obszarze całego Dolnego Śląska i w obrębie Legnicko-Głogowskiego Okręgu Miedziowego (LGOM) wykonano badania gleb warstwy powierzchniowej odpowiednio w roku 1995 (Kijewski, 1995; Lis, Pasieczna, 1995) oraz w latach 1999 (Lis i in., 1999) i 2005 (Lis, Pasieczna, 2005).

\section{METODYKA}

W pracy przedstawiono wyniki badań gleb mineralnych rozwiniętych na utworach fluwioglacjalnych, rzecznych i glinach polodowcowych oraz osadów z czynnego składowiska.

Profile gleb pochodziły z rejonów rolniczych z otoczenia starego zagłębia (1 profil), $\mathrm{z}$ nowego zagłębia (2 profile), $\mathrm{z}$ bezpośredniego otoczenia składowiska zrekultywowanego (1 profil) oraz ze składowiska czynnego (1 profil). Próbki pobierano do głębokości $1,60 \mathrm{~m}, \mathrm{w}$ interwałach co $20 \mathrm{~cm}$. Odczyn $(\mathrm{pH})$ zbadano według procedury przedstawionej przez Mocek i in. (2010), zawartość węglanów określono metodą Scheiblera, a węgiel organiczny metodą Tiurina. Pierwiastki ekstrahowano za pomocą $\mathrm{H}_{2} \mathrm{O}_{2}$. Zawartość $\mathrm{Cu}, \mathrm{Ni}, \mathrm{Zn}$ i $\mathrm{Pb}$ oznaczono w 30 próbkach metodą spektrofotometrii absorpcji atomowej AAS (WNGiG UAM). Uziarnienie zbadano metodą sitową, używając kolumny sit: 2,$0 ; 1,0 ; 0,5 ; 0,25 ; 0,16 ; 0,1 ; 0,071 ; 0,063 \mathrm{~mm}$. Frakcje $<2,0 \mu \mathrm{m}$ oraz $<0,2 \mu \mathrm{m}$ uzyskano przy użyciu wirówki Polygen-Sigma 4-16. Próbki wysuszono, a następnie poddano analizie jakościowej przy pomocy dyfraktometru ARL X'tra Thermo Electron (w Instytucie Geologii UAM), interpretując wyniki przy użyciu programu Win XRD.

\section{WYNIKI}

W glebach ze starego zagłębia użytkowanych rolniczo przeważa najdrobniejsza frakcja. W glebach leśnych nowego zagłębia dominują frakcje $0,5-0,25 \mathrm{~mm}$, a drobne frakcje występują w nielicznych próbkach. Skład ziarnowy wynika głównie z litologii skał macierzystych gleb. W próbkach z osadnika zawartość frakcji piaszczystych stanowi $15 \%$, dominuja frakcje $\mathrm{z}$ przedziału $0,16-0,1 \mathrm{~mm}$ (do $50 \%$ wag.) oraz frakcja $0,16-0,25 \mathrm{~mm}$ (do ok. $38 \%$ wag.). Część osadów odznacza się dużym udziałem frakcji pyłowej $(>0,063 \mathrm{~mm})$.

W glebach leśnych nowego zagłębia odczyn zmienia się w granicach 5-6, a w glebach użytkowanych rolniczo starego zgłębia wynosi 7-9. W glebach starego zgłębia użytkowanych rolniczo węglany występują w ilości $>5 \%$, a na terenie nowego zagłębia nie stwierdzono występowania weglanów

Zawartość badanych metali w glebach jest bardzo zróżnicowana i zmienia się w szerokich granicach. W glebach starego zagłębia stwierdzono do $1082,9 \mathrm{mg} / \mathrm{kg} \mathrm{Cu}$, do $23 \mathrm{mg} / \mathrm{kg} \mathrm{Ni}$, do $49 \mathrm{mg} / \mathrm{kg} \mathrm{Zn}$ oraz ponad $106 \mathrm{mg} / \mathrm{kg} \mathrm{Pb}$. W glebach nowego zagłębia maksymalna zawartość $\mathrm{Cu}$, $\mathrm{Ni}$, Pb i Zn wynosi odpowiednio: niemal $1600 \mathrm{mg} / \mathrm{kg}$,

\footnotetext{
${ }^{1}$ Instytut Geologii, Uniwersytet im. Adama Mickiewicza w Poznaniu, ul. Bogumiła Krygowskiego 12, 61-680 Poznań; duczer@amu.edu.pl,daniel.zimny@amu.edu.pl

${ }^{2}$ Galp Energia SGPS, Rua Toras da Fonseca Tore C, 1600-209 Lisbon, Portugal; natalia.hoska@galp.com

${ }^{3}$ Electroceramics S.A. ul. Świettokrzyska 30/63, 00-116 Warszawa, Poland, marcinzimny12@gmail.com
} 
ponad $33 \mathrm{mg} / \mathrm{kg}, 1200 \mathrm{mg} / \mathrm{kg}$ oraz prawie $90 \mathrm{mg} / \mathrm{kg}$. Ponadto $\mathrm{w}$ glebach nowego zagłębia obserwuje się odwrotną zależność koncentracji metali w stosunku do dystrybucji frakcji ziarnowych - im więcej frakcji grubszych, o średnicach ponad $0,16 \mathrm{~mm}$, tym większa jest koncentracja $\mathrm{Cu}, \mathrm{Pb}$ i Zn. W starym zagłębiu większa koncentracja metali została zanotowana w osadach ilasto-pyłowych. W glebach z obydwu obszarów badań zaznacza się wyraźny spadek zawartości metali wraz z głębokością oraz ze zmniejszaniem frakcji. Na głębokości 20-40 cm zawartość metali jest zwykle mniejsza niż w warstwie powierzchniowej. W skałach macierzystych gleb z głębokości 100-120 cm zawartość poszczególnych metali nie przekracza kilkudziesięciu mg $/ \mathrm{kg}$. Maksymalne koncentracje metali obserwowane w pojedynczych próbkach wynoszą: do $2000 \mathrm{mg} / \mathrm{kg}$ $\mathrm{Cu}$, do $33,6 \mathrm{mg} / \mathrm{kg} \mathrm{Ni}$, do $1300 \mathrm{mg} / \mathrm{kg} \mathrm{Pb}$ oraz do $68,5 \mathrm{mg} / \mathrm{kg}$ Zn w profilu usytuowanym w pobliżu krawędzi osadnika i jednocześnie w pobliżu drogi dojazdowej.

\section{DYSKUSJA}

Obserwowana zawartość ołowiu (1792,6 mg/kg) i cyn$\mathrm{ku}(1129,8 \mathrm{mg} / \mathrm{kg}) \mathrm{w}$ powierzchniowej warstwie gleby oraz w strefie $20-40 \mathrm{~cm}(221,5 \mathrm{mg} / \mathrm{kg} \mathrm{Pb}$ i $162,2 \mathrm{mg} / \mathrm{kg} \mathrm{Zn}$ $\mathrm{w}$ profilu $\mathrm{z}$ nowego zagłębia jest korelowana $\mathrm{z}$ wysoką zawartością miedzi (odpowiednio 1655,1 i 204,4 mg/kg). Uwagę zwraca wyższa zawartość ołowiu niż miedzi, a ze względu na usytuowanie profilu w pobliżu osadnika, w którym zawartości miedzi są znacznie wyższe, wydaje się że ołów jest unieruchomiony w osadach w większym stopniu niż miedź. Maksymalne zawartości niklu nie zawsze pokrywają się z maksymalnymi stężeniami miedzi. W nowym zagłębiu zawartość niklu w profilach przeważnie wzrasta wraz z głębokością.

W rejonie starego zagłębia zróżnicowanie koncentracji metali wiąże się zarówno z odległością od osadnika, jak i położeniem w profilu oraz udziałem frakcji drobnych. $\mathrm{Na}$ obszarze tym maksymalna zawartość miedzi została stwierdzona w profilu usytuowanym najbliżej od osadnika (>2800 mg/kg) (ok. $100 \mathrm{~m})$, ok. $1 \mathrm{~m}$ p.p.t., podczas gdy na głębokości 20-40 cm koncentracja miedzi była mniejsza. Profil ten odzwierciedla miejsce, w którym materiał z osadnika I został przemieszczony na sąsiednie obszary, a górna część została prawdopodobnie zrekultywowana. W pozostałych profilach, usytuowanych w różnych odległościach od osadnika, stwierdzono spadek koncentracji metali, do kilku mg/kg miedzi oraz kilkunastu mg/kg ołowiu i cynku. Większy udział cynku w tym profilu wiąże się prawdopodobnie z zasadowym odczynem oraz obecnością węglanów, które sprzyjają jego unieruchomieniu w środowisku naturalnym.

W badanych profilach wysoka zawartość metali jest warunkowana wartością odczynu, zawartością węglanów, a w największym stopniu uziarnieniem. W nowym zagłębiu miedziowym koncentracje metali są związane podobnie jak w osadnikach - z grubszą frakcją ziarnową, a procesem odpowiedzialnym za rozprzestrzenienie się metali w tym rejonie było najprawdopodobniej wywiewanie materiału z osadnika. W rejonie starego osadnika metale są silnie związane $\mathrm{z}$ drobną frakcją ziarnową, która jest złożona głównie z minerałów ilastych. Rozprzestrzenienie badanych metali w rejonie starego zagłębia miedziowego jest nieznaczne, a wzrost koncentracji miedzi, ołowiu i cynku występuje jedynie w warstwach $0-20$ oraz $20-40 \mathrm{~cm}$. Większość osadów na głębokości 100-120 cm wykazuje niewielkie koncentracje metali, odpowiadające średnim stężeniom w skałach polodowcowych, madach i osadach rzecznych (Czarnowska, 1996).

\section{WNIOSKI}

1. Stężenia miedzi ołowiu i cynku w badanych utworach są ze sobą skorelowane i zawierają się w granicach: 3,0-1082,9 mg/kg Cu, 3,5-106,1 mg/kg Pb; 27,6-49,3 mg/kg Zn oraz 1,33-23,0 mg/kg Ni na obszarach starego zagłębia oraz w zakresach (odpowiednio) dla Cu 0,91-1655,0 mg/kg, $\mathrm{Pb} 10,0-1792,0$ mg/kg, Zn 3,38-1129,0 oraz 0,47-32,7 mg/kg Ni w obszarach nowego zagłębia miedziowego.

2. Koncentracje metali zmieniają się w zależności od pH, zwartości węglanów oraz zróżnicowania frakcji ziarnowych, przy czym w starym zagłębiu uprzywilejowana jest frakcja drobna, a w nowym frakcje $>0,25 \mathrm{~mm}$.

3. Zawartość miedzi w osadach zmienia się w szerokim zakresie w zależności od usytuowania względem osadników oraz od głębokości próbki w profilu. Największe stężenia występują w bezpośredniej bliskości osadników, ale także w pojedynczych profilach w dalszej odległości od osadników.

Pracę wykonano w ramach środków statutowych IG UAM w Poznaniu. Próbka z granicy osadnika była pobierana za zgodą KGHM Polska Miedź S.A., za co autorzy składają uprzejme podziękowania. Autorzy są wdzięczni M. Siepakowi (Zakład Hydrogeologii i Ochrony Wód IG UAM) za umożliwienie i przeprowadzenia analiz chemicznych (WNGiG UAM Poznań), C. Kaźmierowskiemu (Zakład Gleboznawstwa i Teledetekcji Gleb, IGFiKŚP, WNGiG Poznań) za pomoc i oznaczenia składników organicznych oraz M. Kubiakowi (IG UAM) za pomoc laboratoryjną.

\section{LITERATURA}

CZARNOWSKA J. 1996 - Ogólna zawartość metali ciężkich w skałach macierzystych jako tło geochemiczne gleb. Rocz. Gleboznawcze, Suppl., 47, 43-50.

KIJEWSKI P. 1995 - Występowanie metali ciężkich na obszarze środkowego Nadodrza w strefie oddziaływania przemysłu miedziowego. Fizykochemiczne problemy mineralogii, 29: 47-54.

KONSTANTYNOWICZ E. (red.) 1971 - Monografia przemysłu miedziowego w Polsce.

LIS J., PASIECZNA A. 1995 - Atlas geochemiczny Polski w skali $1: 2500$ 000. Państw. Inst. Geol., Warszawa.

LIS J., PASIECZNA A., BOJAKOWSKA I., GLIWICZ T., FRANKOWSKI Z., PASŁAWSKI P., POPIOŁEK E., SOKOŁOWSKA G., STRZELECKI R., WOŁKOWICZ S. 1999 - Atlas geochemiczny Legnicko-Głogowskiego Okręgu Miedziowego w skali 1: 25000. Państw. Inst. Geol., Warszawa.

LIS J., PASIECZNA A. 2005 - Antropogenic soils pollution within the Legnica-Głogów copper district. Państw. Inst. Geol., Sp. Pap., 17: 42-48. MOCEK A., DRZYMAŁA S., MASZNER P. 2010 - Origin, Analysis and Soils Classification. Wyd. UP, Poznań.

OSZCZEPALSKI S. 1999 - Origin of the Kupferschiefer polymetallic mineralization in Poland, Mineral. Dep., 34: 599-613. 